\title{
The Day of Wrath (Dzień gniewu)
}

Author: Roman Brandstaetter

First Published: 1962; second edition, amended, 1971, with the subtitle: "Dramatic mystery play in three acts" and the dedication "Dedicated to the memory of those Poles who died as martyrs from the hands of Hitler's cains, because of the help and shelter given to Jews during the occupation".

Translations: German (Tag des Zornes, 1962); English (The Day of Wrath, 1971); Esperanto (La tago de la kolero, n.d.); French (Le jour de la colère, n.d.); Russian (Den' gneva, 2002).

Theatre Adaptations: (selection) Burgtheater, Vienna (1962); Polish Theater, Los Angeles (1982); Teatr Ludowy, Nowa Huta (1988); Teatr im. Aleksandra Fredry, Gniezno (1989); Teatr Nowy, Lodz (1996); Teatr Nie Teraz, Tarnów (2013)

About the Author: Roman Brandstaetter (1906-1987) was a Polish writer of Jewish origin. He was religiously, culturally and intellectually shaped by the tradition of the Old Testament, but found his identity in Christianity, which he understood as a natural consequence of his Judaism. He graduated with a degree in Polish studies and philosophy at the Jagiellonian University. Before World War II, he travelled around Europe, publishing four volumes of poetry and a collection of pamphlets and writings for the Zionist press. During the war, he lived in - and survived the occupation of - Palestine, where he came to recognise Jesus as the Messiah of the Old Testament and converted to Christianity. Before returning to Poland in 1948, he spent two years in Rome, where he was baptised, married Regina Wiktorówna, and wrote several plays, including his dramatic debut Return of the Prodigal Son (Powrót syna marnotrawnego). In addition to writing for theatre and translating Shakespeare's plays, Brandstaetter also wrote poems, among which the most popularly received would be The Song of My Christ (Pieśń o moim Chrystusie, 1960). His tetralogy Jesus of Nazareth (Jezus z Nazarethu, 1967-1973) is still regarded as a landmark achievement in Polish biblical prose and widely considered to be his opus magnum. Brandstaetter remains one of the best and most famous Polish Christian writers, referring to the philosophical tradition which leads from Saint Augustine, through Saint Francis, Pascal and Kierkegaard to the Christian existentialism of such artists and thinkers as Gabriel Marcel.

\section{Content and Interpretation}

The story is set in Poland during World War II, in a monastery on a hill where the monks pray for enlightenment regarding the Nazi occupation and find it in the secret of God's destiny. Their anxiety is caused by visits paid to the prior of the monastery by the head of the local Gestapo, Sturmbannführer SS Born. The situation becomes more

Ә Open Access. ( 2021 Dariusz Kulesza, published by De Gruyter. (cc) BY-NC-ND This work is licensed under a Creative Commons Attribution-NonCommercial-NoDerivatives 4.0 License. https://doi.org/10.1515/9783110671056-023 
complicated when Emanuel Blatt, a runaway Jew, comes to the monastery. The monks are initially frightened and unwilling to help him. When Blatt announces he will leave the monastery they are initially silent, but they decide finally to stop him from leaving and allow him to stay. The prior accepts their decision, and is soon forced to accept the visit of Born, a former colleague from the seminary in Rome who has abandoned his studies and chosen to follow Nazi ideology. Julia Chomin, a former prostitute, is next to visit the prior. She reproaches the priest for a sermons he gave years ago but has now forgotten, a sermon in which he condemned her profession. Blackmailing him with the knowledge that the monastery is hiding a Jew, she demands - unsuccessfully - that the prior give her a string of pearls from the altar of the Virgin Mary. In the second act, the prior is visited by a representative of the underground, who trusts him because of the help the monastery has given to the Jew. The visitor reveals that Julia is Born's lover, and asks the clergyman for a sign that would help them ambush the Gestapo officer. The prior, faithful to the fifth commandment, and without losing hope in converting the German, refuses. The prior is then confronted by Blatt, who has lost all faith in Christians and blames them for the Holocaust. In response, the priest points to Jesus, who suffers in every Jew condemned to death. The centre of the third act is the torture of Blatt staged by Born to resemble the Passion of Christ. This happens after Blatt has revealed himself to the Gestapo officer, who had blackmailed the prior, threatening to execute the monks and spare only him if the Jew was not released. Like Jesus, Blatt moves Born, reminding him of the God he has abandoned. The German kills Julia, who appears in the monastery once more to demand the pearls. Before leaving the monastery, Born involuntarily gives a sign to the underground soldiers, sealing his death. At the end of the play, Blatt recognises Jesus on the cross as God of the Old Testament.

Brandstaetter looks to the Gospels for answers to all questions posed by reality. The foundation of his work is the conviction that this is the attitude required by faith. The Day of Wrath is a drama confronting Christianity with the Holocaust. In searching for the causes of the Holocaust, Brandstaetter favours the individual and religious perspective to the exclusion of all others. Born, who directs the extermination of Jews, is a former cleric, who has abandoned God. His Polish friend from the seminary, the prior, neither comes from an innocent nation nor is blameless himself - including in his dealings with Blatt, who is seeking help -, but the prior knows that he will meet the moral requirements of his conscience if he remains faithful to the Judeo-Christian God. This God leaves neither the prior, nor other characters of the drama alone. He reveals himself in the Jew tortured by Born. He reveals the power of weakness, of humiliation and of the cross, his power, which oversees history in an incomprehensible way, and which at the same time accompanies those who are its victims. The Day of Wrath is widely seen today as "the most difficult - in many places controversial and most painfully personal of Brandstaetter's plays” (Trojanowska, Stępniak, 2015, p. 22). 


\section{Main Topics and Problems}

The Day of Wrath, inscribed in the current of poetic theatre (Zajączkowski, 2007, p. 414), has been interpreted variously as a drama that indirectly addresses the subject of the Holocaust (Kurzyna, 1964, p. 1) and as a mystery play focused on religious issues, as read in the context of the language and content of the Bible. Some have identified the mystical aspect of the play, highlighting moral issues entangled in existential perspectives, confronted with transcendence (Bednarczyk, 2002). Above all, however, this is a text that establishes the relationship between a historical liminal experience: the Holocaust and Christianity. Brandstaetter defines this relationship by taking up the subject of Jewish-Christian religious relations, the responsibility of Christians for the Holocaust, and even Jewish participation in the Holocaust. All this takes place on an individualised existential plan, confronting faith with History.

Brandstaetter's drama is a false theodicy, because God, like in the Book of Job, does not need justification here. One may assume responsibility for evil - for the Holocaust, in this text - as a matter of faith, as a matter even of martyrdom. Or one may reject it, to take the side of evil. History in The Day of Wrath has an apocalyptic dimension, but it is carried out by people. God deploys it as a sign that verifies every human being. The humanism in The Day of Wrath is subordinated to morality, built on faith and treated as the most important substance of existence. The theology and historiosophy of the drama have an orthodox Christian character, marked by the severe, demanding and unforgiving character of the Old Testament and classical Greek tragedy.

\section{Cited Works}

Bednarczyk E. (2002). Człowiek wobec transcendencji i tajemnicy człowieczeństwa. Studium na podstawie dramatu Dzień gniewu Romana Brandstaettera. Orbis Linguarum, (20), pp. 285-299. Eustachiewicz, L., Górski, J., Kowalska, A., Kurzyna, M., Łączkowski, Z., Szczawiński, J., Żwira, T. (1964). Dzień gniewu i łaska krzyża (Rozmowa o dramacie Brandstaettera). Kierunki, 11(404), pp. 1-2. Trojanowska, T., Stępniak, B. (2015). Teatr odwagi. In: R. Brandstaetter, Dzień gniewu. Dramaty. Warsaw: Wydawnictwo IBL PAN, pp. 7-36. Zajączkowski, R. (2007). Christ's Witness: among Meanings and Contexts of Roman Brandstaetter's Writings. The Polish Review, 52(4), pp. 407432.

\section{Further References}

Jasińska, Z. (1991). Religijne wątki w dramaturgii Brandstaettera. In: I. Sławińska, W. Kaczmarek, eds., Dramat i teatr religijny w Polsce. Lublin: Scientific Society of the Catholic University of Lublin, pp. 401-417. Krawiecka, E. (2005). „Moim domem jest światło“. Roman Brandstaetter jako dramaturg. In: R. Brandstaetter, Dramaty. Kraków: Wydawnictwo M, pp. 5-15. Kryńska, H. (2011). Czas gniewu, czas miłosierdzia. Księgi Starego Testamentu w Dniu gniewu Romana Brandstaettera. Roczniki Humanistyczne, 59(1), pp. 149-175. Mazan-Mazurkiewicz, A. (2002). The Notifs and Ideas of 
Biblical Origin in the Literary Work of Roman Brandstaetter. Acta Universitatis Lodziensis. Folia litteraria Polonica, 5, pp. 173-174. Strzelecki, R. (1996). Dzień gniewu Romana Brandstaettera. Próba interpretacji dramatu. In: Z. Andres, ed., W stronę współczesności. Studia i szkice o literaturze polskiej po 1939 roku. Rzeszów: Wydawnictwo Wyższej Szkoły Pedagogicznej, pp. 167-182.

DK 